\title{
Adipose Tissue-Derived Stem Cell in Vitro Differentiation in a Three-Dimensional Dental Bud Structure
}

\author{
Federico Ferro, ${ }^{*}$ Renza Spelat, ${ }^{*}$ Giuseppe Falini, ${ }^{\dagger}$ \\ Annarita Gallelli, ${ }^{\ddagger}$ Federica D’Aurizio, ${ }^{\ddagger}$ \\ Elisa Puppato, ${ }^{\mp}$ Maura Pandolfi, ${ }^{\neq}$ \\ Antonio Paolo Beltrami, ${ }^{\ddagger}$ Daniela Cesselli, ${ }^{\ddagger}$ \\ Carlo Alberto Beltrami, ${ }^{+}$ \\ Francesco Saverio Ambesi-Impiombato, * \\ and Francesco Curcio*

\begin{abstract}
From the Department of Patbology and Experimental and Clinical Medicine, ${ }^{*}$ and the Centre of Regenerative Medicine, ${ }^{*}$ University of Udine, Udine; and the Department of Chemistry

"G. Ciamican," Alma Mater Studiorum University of Bologna,
\end{abstract} \\ via Selmi, Bologna, Italy
}

Tooth morphogenesis requires sequential and reciprocal interactions between the cranial neural crest-derived mesenchymal cells and the stomadial epithelium, which regulate tooth morphogenesis and differentiation. We show how mesenchyme-derived single stem cell populations can be induced to transdifferentiate in vitro in a structure similar to a dental bud. The presence of stem cells in the adipose tissue has been previously reported. We incubated primary cultures of human adipose tissue-derived stem cells in a dental-inducing medium and cultured the aggregates in three-dimensional conditions. Four weeks later, cells formed a three-dimensional organized structure similar to a dental bud. Expression of dental tissue-related markers was tested assaying lineagespecific mRNA and proteins by RT-PCR, immunoblot, IHC, and physical-chemical analysis. In the induction medium, cells were positive for ameloblastic and odontoblastic markers as both mRNAs and proteins. Also, cells expressed epithelial, mesenchymal, and basement membrane markers with a positional relationship similar to the physiologic dental morphogenesis. Physical-chemical analysis revealed 200-nm and $50-\mathrm{nm}$ oriented hydroxyapatite crystals as displayed in vivo by enamel and dentin, respectively. In conclusion, we show that adipose tissue-derived stem cells in vitro can transdifferentiate to produce a specific three-dimensional organization and pheno- type resembling a dental bud even in the absence of structural matrix or scaffold to guide the developmental process. (Am J Pathol 2011, 178:2299-2310; DOI: 10.1016/j.ajpath.2011.01.055)

In the Western world, an estimated $85 \%$ of adults need dental treatment. By the age of 17 years, approximately $7 \%$ of the population has lost one or more teeth. After the age of 50 years, an average of 12 teeth have been lost. This means that there is a significant drain on health care resources. Although tooth loss does not represent an immediate life threat, it may decrease life expectancy, and certainly it is responsible for a decreased quality of life. ${ }^{1}$ It is known that synthetic materials provide dental functional repair but not anatomical and functional structure regeneration. The current approach comprises mainly bone-integrated metallic dental implants, developed by many companies. Despite the recent technical developments, such implants often still cause many problems for the patient.

Many animals, such as fish and reptiles, regenerate teeth a few times during their life span, whereas others, such as rodents, have continuously growing teeth. Commonly, humans have their teeth replaced only once. However, it has been reported that some people have a third generation of teeth or have a supranumeral tooth, indicating the possibility that the capacity to regenerate teeth may be present throughout life. A better knowledge of tooth morphogenesis may provide a way to develop better regenerative approaches to tooth replacement. Basically, tooth morphogenesis, as in other organs, consists of sequential and reciprocal interactions between the cranial neural crest-derived mesenchymal cells and the

\footnotetext{
Supported partially by Agenzia Spaziale Italiana through the MoMa Project.

F.F. and S.R. contributed equally to this work.

Accepted for publication January 10, 2011.

Supplemental material for this article can be found at http://ajp. amjpathol.org or at doi: 10.1016/j.ajpath.2011.01.055.

Address reprint requests to Francesco Curcio, M.D., Department of Pathology and Experimental and Clinical Medicine, University of Udine, P.le S. Maria della Misericordia, 33100 Udine, Italy. E-mail: curcio@uniud.it.
} 
oral epithelium, which regulate tooth morphogenesis and differentiation. The first morphologic sign of tooth development appears as a local thickening of the dental epithelium. During this process, the presumptive dental epithelial cells elongate along their apical-basal axis, change cell shape from cuboidal to columnar, assume an apical-basal polarity (polarization), and form a dental placode. At the bud stage, the thickened dental epithelium proliferates and invaginates into the subjacent mesenchyme to form the epithelial tooth bud around which the mesenchymal cells condense. During these stages, the basal layer cells of the epithelial bud maintain a columnar shape. At the cap stage, the epithelial component undergoes specific folding, which is accompanied by the formation of the enamel knot, a transient cluster of nondividing epithelial cells. The enamel knot is therefore considered to be a signaling center controlling the pattern of the tooth cusps. During the subsequent bell stage, the epithelium-derived ameloblasts and mesenchyme-derived odontoblasts start to secrete extracellular matrix proteins (Figure 1). ${ }^{2,3}$

As already shown, productive interactions between different tissues are the basic language needed for organ or tissue development. Previous experiments reported that single-cell suspensions, dissociated from the third molar tooth germs and seeded on biodegradable scaffolds, formed tooth structures containing dentin, odontoblasts, a well-defined pulp chamber, putative Hertwig's root sheath epithelia, and enamel organ. It has also been demonstrated that mouse stem cells, including embryonic stem cells, neural stem cells, and bone marrow-derived stem cells, could be reprogrammed to support tooth formation. These cells, when aggregated and recombined with the embryonic mouse molar epithelium, which possesses the odontogenic potential, could respond to inductive signals from the dental epithelium and initiate odontogenesis. ${ }^{4-8}$ It was also reported that embryonic oral-derived mesenchymal cells, which possess the odontogenic potential, recombined with epithelial cells could respond to inductive signals from mesenchymal cells and initiate odontogenesis. ${ }^{9}$

These studies support the idea that the odontogenic process can be initiated in stem cells of nondental origin when proper odontogenic signals are provided, but the main limiting factor of these procedures is that the mesenchymal or epithelial cells derived from dental buds or
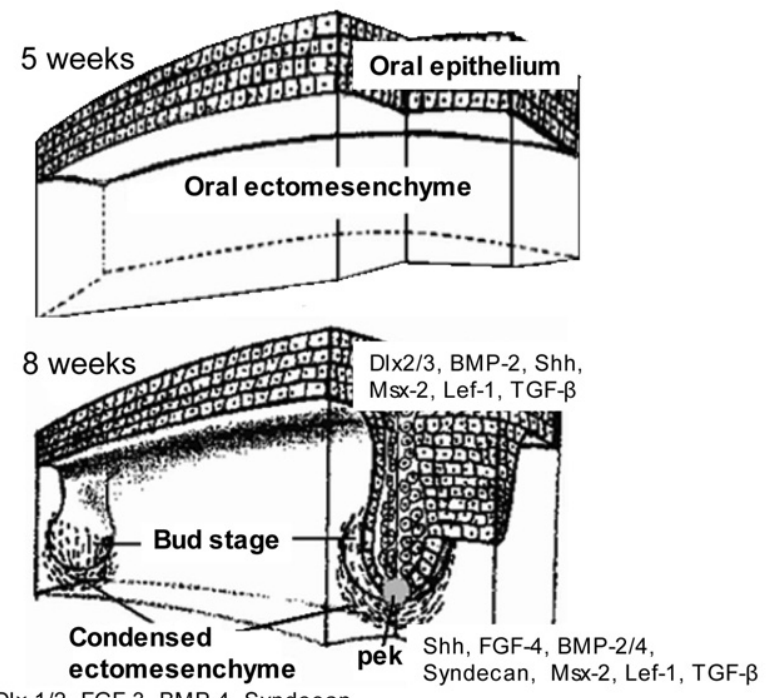

DIx-1/2, FGF-3, BMP-4, Syndecan, Msx-1, Pax-9, Lef-1, TGF- $\beta$
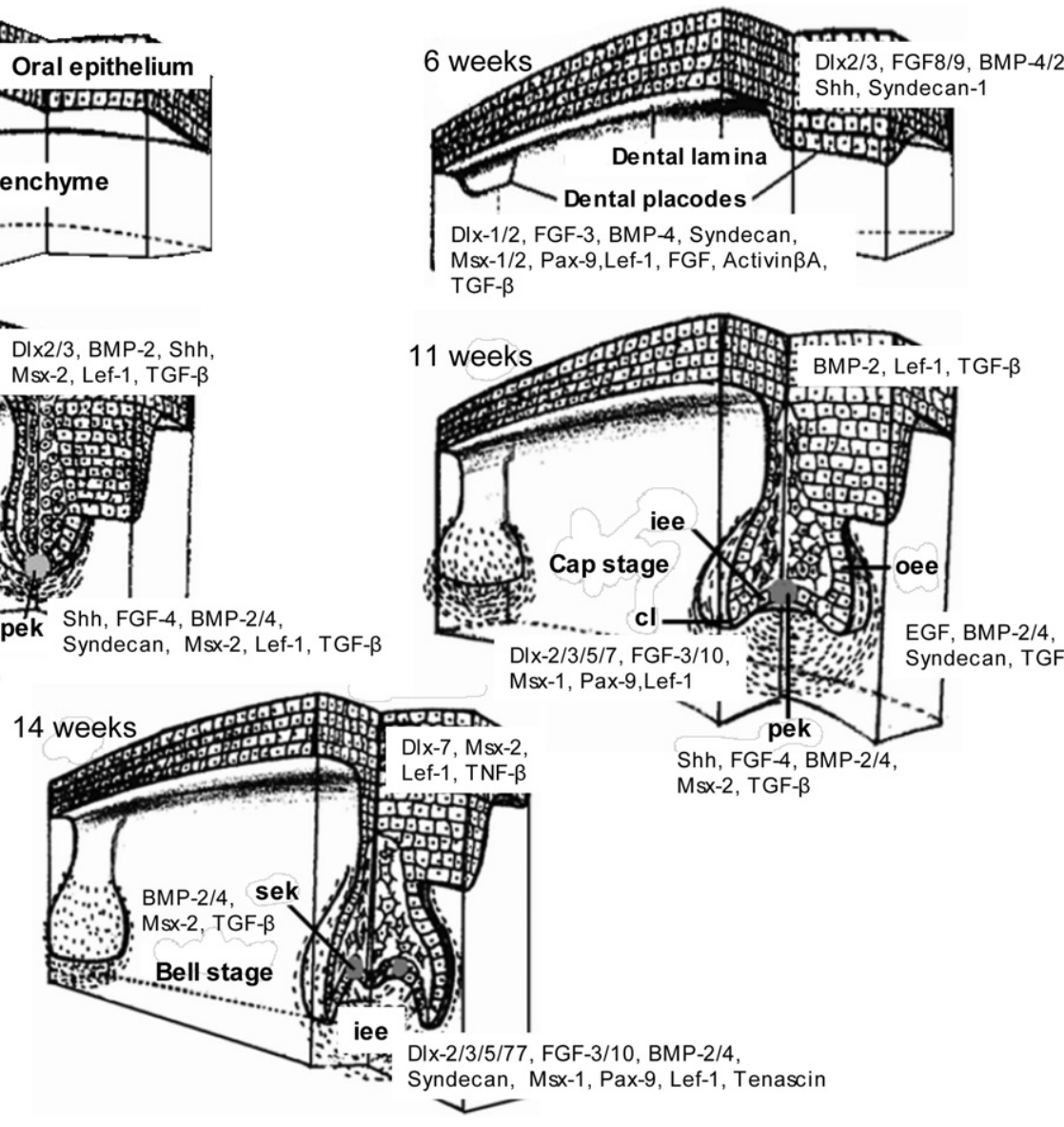

Msx-1/2, Pax-9,Lef-1, FGF, Activin $\beta A$

TGF- $\beta$

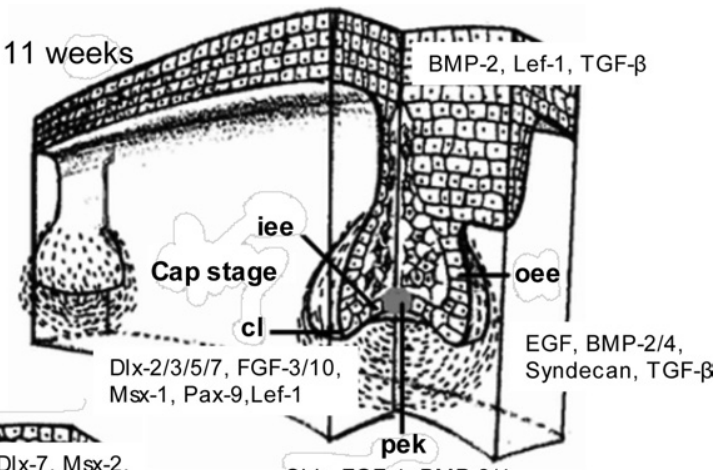

Shh, FGF-4, BMP-2/4

MsX-2, TGF- $\beta$

Figure 1. Stages and signaling in human teeth development. Figure shows the stages of tooth development, signaling molecules, and growth factors expressed in the epithelial and mesenchymal components of developing teeth. At 5 weeks, prepatterned oral ectoderm is in close contact with cranial, neural crest ectomesenchyme. At this stage the odontogenic potential resides in the epithelium. At 6 weeks, the epithelial cells secrete specific signals in different areas, proliferate, and form a band of epithelial tissue, the dental lamina, and the dental placodes. At 8 weeks, at the sites of the dental placodes, the epithelial cells proliferate and intrude within the mesenchyme, forming the tooth buds. At this developmental stage, the odontogenic potential is lost from the epithelium and granted to the ectomesenchyme. At 11 weeks, the bud folds in and acquires initially the form of an inverted cap and later the form of a bell ( $14 \mathrm{weeks}$ ). cl, cervical loop; iee, inner enamel epithelium; oee, outer enamel epithelium; pek, primary enamel knot; sek, secondary enamel knots. Modified with permission from Koussoulakou et al. A curriculum vitae of teeth: evolution, generation, regeneration. Int J Biol Sci 2009, 5:226-243. ${ }^{3}$ 
embryonic tissues are not readily available, making this approach interesting but not practical.

We tried a different approach, seeking in vitro dental bud regeneration using a single adult mesenchymal stem cell population to achieve tooth regeneration, as also proposed by Ikeda et $\mathrm{al}^{10}{ }^{10}$ with the intent to overcome problems originating from the availability of dental buds.

\section{Materials and Methods}

To isolate adipose tissue-derived stem cells (ASCs), nine raw human abdominal lipoaspirates, obtained with the informed consent of the donors (28 to 35 years old), were washed in PBS solution and then dissociated in Dulbecco's modified Eagle's medium (DMEM; Sigma-Aldrich, St. Louis, MO) containing $400 \mathrm{U} / \mathrm{mL}$ of collagenase type 2 (Wortington, Lakewood, NJ) for 15 minutes at $37^{\circ} \mathrm{C}$. Samples were centrifuged for 15 minutes at $1,800 \times g$, then pellets were resuspended and filtered through a $70-\mu \mathrm{m}$ pore-sized membrane. Filtered cells were plated into 100-mm dishes $\left(2 \times 10^{6}\right.$ cells per dish $)$ in proliferation medium, derived from Gronthos et al, ${ }^{11}$ composed of F-12 Coon's and Ambesi's modified medium (Gibco-Invitrogen, Carlsbad, CA), Medium-199, and CMRL-1066 media (Sigma) supplemented with $1.25 \%$ type 0 human serum, $25 \mathrm{ng} / \mathrm{mL}$ of platelet-derived growth factor-bb, 25 $\mathrm{ng} / \mathrm{mL}$ of epidermal growth factor, $25 \mathrm{ng} / \mathrm{mL}$ of insulin-like growth factor $1,25 \mathrm{ng} / \mathrm{mL}$ of fibroblast growth factor-b (FGF-b; all from Immunotools, Friesoythe, Germany), $10^{-9} \mathrm{~mol} / \mathrm{L}$ dexamethasone (MP Biomedicals, Solon, $\mathrm{OH}$ ), $90 \mu \mathrm{g} / \mathrm{L}$ of linoleic acid (Sigma), $25 \mathrm{mg} / \mathrm{L}$ of ascorbic acid (Sigma), and $25 \mu \mathrm{g} / \mathrm{mL}$ of gentamicin (Gibco). Colonies developed in primary culture and reached near confluency in approximately 1 week. ASCs were maintained semiconfluent to prevent cell differentiation, and approximately $80 \%$ of the medium was replaced every 3 days. Primary human bone marrow mesenchymal stem cells (MSCs) and dental pulp stem cells (DPSCs) were obtained as described by Ferro et al. ${ }^{12}$ Human bone MSCs were obtained by flushing the femur head content through a 26-gauge needle. Flushed cells were diluted in Hanks' balanced salt solution (Sigma), layered on top of Ficoll (Amersham), and centrifuged. Finally, buffy coat was washed twice with Hanks' balanced salt solution and subjected to immunodepletion using RosetteSep (Stemcells Technologies, Vancouver, British Columbia). ${ }^{13,14}$ Then $1.5 \times 10^{6}$ of freshly isolated cells, derived from primary culture, were plated in 100-mm dishes (BD Falcon, San Jose, CA). Dental pulps were extracted from human deciduous teeth of 5 - to 7-year-old children (with parents' permission) using a syringe needle and were transferred to $35-\mathrm{mm}$ Petri dishes (BD Falcon); human DPSC colonies developed in primary culture and usually reached confluence approximately 2 weeks later; both MSCs and DPSCs were made to proliferate in the same medium used for ASCs.

Human supranumeral teeth buds were isolated following the same methods used for DPSCs; were cultured in DMEM/F-12 (Gibco) containing 20\% fetal bovine serum supplemented with $0.18 \mathrm{mg} / \mathrm{mL}$ of ascorbic acid (Sigma), $2 \mathrm{mmol} / \mathrm{L} \mathrm{L-glutamine} \mathrm{(Sigma),} \mathrm{and} 50 \mathrm{U} / \mathrm{mL}$ of penicillin/ streptomycin (Gibco) ${ }^{8}$; and were used as amelo-odontoblastic positive control cells. Human primary thyroid cells, used as negative controls in RT-PCR and immunoblot, were cultured according to the method of Curcio et al. ${ }^{15}$ Human embryonic carcinoma stem cells (Ntera2), used as a positive control for embryonic stem cell markers as suggested by Liedtke et al, ${ }^{16}$ were cultured in DMEM (Gibco), supplemented with $4.5 \mathrm{~g} / \mathrm{L}$ of glucose, $4 \mathrm{mmol} / \mathrm{L}$ L-glutamine, $10 \%$ fetal bovine serum, and $50 \mathrm{U} / \mathrm{mL}$ of penicillin/streptomycin (Gibco). ${ }^{17}$

\section{FACS Analysis}

Fluorescence activated cell sorter (FACS) analysis was performed on noninduced passage 3 (P3) ASCs previously detached by a short incubation in $22 \mathrm{U} / \mathrm{mL}$ of collagenase type 2 and $0.5 \mathrm{U} / \mathrm{mL}$ of trypsin (Sigma). Detached cells were washed in ice-cold blocking buffer, Minimum Essential Medium (MEM)/HEPES plus 2\% bovine serum albumin (BSA), and incubated for 30 minutes on ice in blocking buffer containing conjugated cluster differentiation primary antibodies [fluorescein isothiocyanate (FITC) or phycoerythrin-thanolamine conjugated] against CD10 (332775), CD13 (3474406), CD29 (556049), CD34 (345801), CD44 (347943), CD45 (345808), CD49a (559596), CD49d (555503), CD59 (555764), CD73 (550257), CD90 (555596), CD117 (332785) (all from BD, San Jose, CA), CD66e (MCA1744F; Serotec, Raleigh, NC), CD105 (MCA1557PE; Serotec), CD133 (Miltenyi Biotec 30-080-801; Bergisch, Gladbach, Germany), KDR (FAB357P; R\&D Systems, Minneapolis, MN), and vascular endothelial cadherin (SC9989; Santa Cruz, Santa Cruz, $\mathrm{CA}$ ), each one used at a concentration of $0.1 \mu \mathrm{g}$ per $1 \times$ $10^{6}$ cells. Isotype-matched conjugated antibodies were used as negative controls. Data (20,000 events) were collected from three independent experiments using a FACS-Calibur (BD) and were expressed as mean \pm SD.

\section{Immunofluorescence}

Undifferentiated and differentiated P3 ASCs and positive and negative control cells were washed with PBS, fixed using $4 \%$ paraformaldehyde in PBS for 20 minutes at room temperature, and quenched in Tris-buffered saline (TBS) $0.2 \%$ glycine in agitation for 10 minutes. Intracellular staining was performed by incubating cells with $0.25 \%$ Triton X-100 (Sigma) for 10 minutes at room temperature and blocking in TBS 5\% BSA for 30 minutes. Primary antibodies against Nanog (Ab21603, diluted 1:125) and Oct4A (Ab18976, diluted 1:200) (all from Abcam, Cambridge, MA) were diluted in TBS containing $1.5 \%$ BSA and $0.2 \%$ Tween 20 and were incubated overnight at $4^{\circ} \mathrm{C}$. Secondary antibody, anti-rabbit IgG FITC conjugated (F9887, diluted 1:400; Sigma), was incubated 1 hour at room temperature, and nuclear counterstaining was performed using DAPI (Pierce, Rockford, IL) diluted in Vectashield (Vector Laboratories, Burlingame, CA). Image acquisition was performed by a Leica DMI 6000B microscope connected to a Leica DFC350FX camera (Leica, Milan, Italy). Adobe Photoshop software was used 
to compose and overlay the images and to adjust contrast (Adobe, San Jose, CA).

\section{Dental Bud Differentiation}

Approximately $30 \times 10^{6}$ P3 ASCs were mechanically detached (scraped) and centrifuged at 10,000 $\times g$ in 50-mL tubes. Pellets were then transferred to $100-\mathrm{mm}$ dishes, overlayered by $2 \%$ agarose diluted $1 / 1$ in differentiation medium, to form a three-dimensional structure (aggregates).

To induce differentiation, ASC aggregates were cultured in BJG medium (Gibco) additioned with 6.5\% Medium-199 (Sigma) and supplemented with $1 \mathrm{ng} / \mathrm{mL}$ of FGF-4, $0.5 \mathrm{mmol} / \mathrm{L} \beta$-glycerophosphate, $3.3 \mathrm{mg} / \mathrm{L}$ of ascorbic acid 3-phosphate, $0.3 \mathrm{mmol} / \mathrm{L} \mathrm{CaCl}_{2}, 17.6$ $\mathrm{ng} / \mathrm{mL}$ of bone morphogenetic protein (BMP) 5, 1.9 $\mathrm{ng} / \mathrm{mL}$ of $1-25$-hydroxy- $\mathrm{D}_{3}$ vitamin, $0.12 \mu \mathrm{g} / \mathrm{mL}$ of fibronectin, $0.5 \mathrm{nmol} / \mathrm{L}$ calcitonin (all from Sigma), $5 \mathrm{ng} / \mathrm{mL}$ of insulin-like growth factor 2, $12.5 \mathrm{ng} / \mathrm{mL}$ of BMP-2, 1.5 $\mathrm{ng} / \mathrm{mL}$ of transforming growth factor- $\beta 1,2 \mathrm{ng} / \mathrm{mL}$ of BMP-4, $2.2 \mathrm{ng} / \mathrm{mL}$ of vascular endothelial growth factor (all from Peprotech, London, England), $25 \mu \mathrm{g} / \mathrm{mL}$ of gentamicin (Gibco), and $2.5 \%$ human type 0 serum obtained from healthy volunteers with permission. To demonstrate physical-chemical hydroxyapatite $(\mathrm{HA})$ nanocrystal differential characteristics, $5 \times 10^{6}$ P4 DPSCs and MSCs were allowed to aggregate by the same methods used for ASCs in the presence of the osteoblastic medium. Dental differentiation experiments were repeated three times and investigated after 1 month by molecular characterization.

\section{Osteoblastic Differentiation}

To demonstrate chemical-physical HA nanocrystal differential characteristics, $5 \times 10^{6}$ P4 DPSCs and MSCs were allowed to aggregate by the same methods used for ASC dental induction in the presence of the following osteoblastic media, developed as already described by Beltrami et $\mathrm{al}^{18}$ and D'lppolito et $\mathrm{al}^{19}$ with some modifications: F-12 Coon's and Ambesi's modified medium with $100 \mathrm{nmol} / \mathrm{L}$ dexamethasone, $250 \mathrm{nmol} / \mathrm{L}$ retinoic acid, 1 $\mu \mathrm{mol} / \mathrm{L} 17-\beta$-estrogen, $1 \mathrm{nmol} / \mathrm{L}$ calcitonin (all from MP Biomedicals), $1 \mathrm{mmol} / \mathrm{L} \beta$-glycerophosphate, $1.2 \mathrm{mmol} / \mathrm{L}$ $\mathrm{CaCl}_{2}, 0.6 \mathrm{mmol} / \mathrm{L} \mathrm{MgCl} 2,2 \mathrm{~g} / \mathrm{L}$ of glucose, $1 \mu \mathrm{mol} / \mathrm{L} \mathrm{K}{ }_{2}$ vitamin, $5 \mathrm{nmol} / \mathrm{L}$ 1-25-hydroxy- $\mathrm{D}_{3}$ vitamin (all from Sigma), $0.5 \%$ type 0 human serum, and $15 \mathrm{ng} / \mathrm{mL}$ of BMP-2 (Immunotools). Dental and osteoblastic differentiations were performed in a $5 \% \mathrm{CO}_{2}$ incubator at $37^{\circ} \mathrm{C}$, and medium was exchanged twice a week. Dental differentiation was detected after 1 month by molecular characterization, whereas 3-month dental-induced ASC aggregates and osteoblastic-induced DPSC and MSC aggregates were subjected to physical-chemical analysis.

\section{$R T-P C R$}

To demonstrate the presence of stem- and dental-related markers, we used specific primers to detect Oct4 isoform A, Nanog, amelogenin, ameloblastin, enamelin, and dentin sialoprotein (DSP) in proliferating ASCs, 1-month dif- ferentiated ASC aggregates, and positive and negative control cells. Total RNA was extracted from P3 samples using TRIzol (Gibco) as previously described ${ }^{20}$; total RNA samples were then quantified by spectrophotometer. After DNase I (Ambion, Carlsbad, CA) treatment, first strand cDNA synthesis was performed with $1 \mu \mathrm{g}$ of total RNA using random hexanucleotides and M-MLV reverse transcriptase (Invitrogen). PCR amplification was performed in a final volume of $50 \mu \mathrm{L}$, using $100 \mathrm{ng}$ of CDNA, 10 $\mathrm{mmol} / \mathrm{L}$ Tris- $\mathrm{HCl}(\mathrm{pH} 9.0), 1.5 \mathrm{mmol} / \mathrm{L} \mathrm{MgCl}_{2}, 0.2 \mathrm{mmol} / \mathrm{L}$ dNTPs, 50 pmol of each primer, and $2 \mathrm{U} / \mu \mathrm{L}$ of Taql polymerase (Amersham, Piscataway, NJ). Primer sequences, PCR product sizes, annealing temperatures, and gene bank accession numbers are as follows: Oct4 isoform A, 5'-GTGGAGAGCAACTCCGATG-3', 5'-TGCAGAGCTTTGATGTCCTG-3', 121 bp, 56 ${ }^{\circ} \mathrm{C}$, NM002701.4; Nanog, 5'-ATGCCTCACACGGAGACTGT-3', 5'-AGGGCTGTCCTGAATAAGCA-3', 66 bp, 56 $\mathrm{C}$, NM_024865; amelogenin, 5'-GAAATGGGGACCTGGATITA-3', 5'-TGTTGGATTGGAGTCATGGAG-3', isoform $3,385 \mathrm{bp}$, isoform 2, $295 \mathrm{bp}$, isoform $1,343 \mathrm{bp}, 54^{\circ} \mathrm{C}$, NM_182680.1, NM_182681.1, NM_001142.2; ameloblastin, 5'-TCAAAATGAAGGACCTGATAC-3', 5'-GAGTTTCATGTTCTCTTGGCCTC-3', 263bp, 56 ${ }^{\circ} \mathrm{C}, \quad$ NM_016519.4; Enam, 5'-ACAACCACCATGGCAAATTC-3', 5'-ATTGGTGGGCGTCCATAAC-3', 59bp, 54 ${ }^{\circ} \mathrm{C}$, NM_031889.2; DSP, 5'-GCATTTGGGCAGTAGCATGG-3', 5'-CTTTTCCTGTGTCCCCATTCC-3', 324bp, 53으, NM_014208.3; $\beta$-actin, 5'-GCACTCTTCCAGCCTTCCTTCCTG-3', 5'GGAGTACTTGCGCTCAGGAGGAGC-3', 253 bp, 56 ${ }^{\circ} \mathrm{C}$, NM_001101.3. The reaction products were visualized on ethidium bromide-stained $1 \%$ to $2 \%$ agarose gels. Images were collected using Gel-Doc 2000 (Bio-Rad, Hercules, CA), and $\beta$-actin was used as the normalizer.

\section{Immunoblot}

Whole cell extracts for positive and negative controls and proliferating and dental-induced ASCs were prepared by using lysis buffer [25 mmol/L HEPES (pH 7.6) $0.3 \mathrm{~mol} / \mathrm{L}$ $\mathrm{NaCl}, 1.5 \mathrm{mmol} / \mathrm{L} \mathrm{MgCl}_{2}, 0.2 \mathrm{mmol} / \mathrm{L}$ EDTA, $0.5 \%$ Nonidet $\mathrm{P} 40,0.5 \mathrm{mmol} / \mathrm{L}$ dithiothreitol, $1 \times$ protease inhibitor, 1 $\mathrm{mmol} / \mathrm{L} \mathrm{NaF}$, and $1 \mathrm{mmol} / \mathrm{L} \mathrm{Na}$ ortovanadate, all from Sigma] as described by Ferro et al. ${ }^{12}$ Samples protein content was quantified by BCA protein assay reagent kit (Pierce) and the program Labsystems genesis V2.16. A total of $20 \mu \mathrm{g}$ of the total protein extracts of each sample were separated by SDS-polyacrylamide gel electrophoresis. After protein transfer onto nitrocellulose (Schleicher \& Schuell, Keene, $\mathrm{NH}$ ), blots were blocked in TBS with $5 \%$ BSA and $0.5 \%$ Tween 20 , then reacted with primary antibodies against: amelogenin (SC32892, diluted 1:2000), ameloblastin (SC32892, diluted 1:300), enamelin (SC33107, diluted 1:300), and DSP (SC33586, diluted 1:1500) (all from Santa Cruz), whereas anti- $\alpha$-tubulin (T9026, diluted 1:5000; Sigma) antibody was used to demonstrate equal protein loading. Secondary antibodies, anti-mouse (32430, diluted 1:4000; Pierce), anti-rabbit (32460, diluted 1:5000; Pierce), anti-goat (A5420, diluted 1:100,000; Sigma), were incubated in TBS plus 5\% BSA and 1\% Tween 20 at room temperature for 1 hour. 
Antibody/antigen complexes were detected using an electrochemiluminesce reagent (Amersham).

\section{Immunohistochemistry}

Aggregates were rinsed in PBS and fixed in buffered formalin for 2 hours, then were included in paraffin and sectioned (at $5 \mu \mathrm{m}$ ). Representative sections were stained using hematoxylin-eosin (Sigma) to evaluate three-dimensional morphology of aggregates. Sections were deparaffinized and incubated with $3 \%(\mathrm{v} / \mathrm{v})$ hydrogen peroxide in methanol. Rehydrated sections were subjected to epitope recovering in citrate buffer at $95^{\circ} \mathrm{C}$ for 30 minutes. Once room temperature was reached, slides were washed in TBS and nonspecific immunoglobulin binding was blocked by $5 \%(\mathrm{v} / \mathrm{v})$ BSA in TBS for 35 minutes at room temperature. Sections were incubated overnight at $4^{\circ} \mathrm{C}$ with the following primary antibodies: anti-ameloblastin (diluted 1:60), amelogenin (diluted 1:150), enamelin (diluted 1:50), DSP (diluted 1:250), matrix metalloproteinase (MMP) 20 (M5934, diluted 1:200; Sigma), MMP-2 (Ms806-P0, diluted 1:50) (Neomarkers, Thermo Fisher Scientific, Fremont, CA), $\beta_{1}$-integrin (SC9970, diluted 1:40; Santa Cruz), collagen type 3 (SC271249, diluted 1:100; Santa Cruz), collagen type 4 (M-0785, diluted 1:100; DakoCytomation, Glostrup, Denmark), cytokeratin (CK) 19 (SC6278, diluted 1:50; Santa Cruz), Ck-14 (Ab9220, diluted 1:50; Abcam), Ck-13 (MUC255-UC, diluted 1:10; Biogenex, San Ramon, CA), $\mathrm{N}$-cadherin (N-cad; 33-3900, diluted 1:40; Zymed, Carlsbad, CA), and E-cadherin (E-cad; MAB-3199Z, diluted 1:200; Chemicon, Temecula, CA). Immunohistochemical reaction was performed with labeled streptavidin biotin (LSAB), horseradish peroxidase staining kit (Dako), incubating dental-induced aggregates, and negative control sections for 20 minutes at room temperature with universal biotinylated link immunoglobulin and for 20 minutes with diluted streptavidin-conjugated reagent. Reaction was developed with diaminobenzidine chromogen substrate for a variable time, 1 to 5 minutes. The specimens were counterstained with hematoxylin, dehydrated, and examined by light microscopy. Human ventricular heart tissue was used as negative control.

\section{Preparation for Biochemical and Biophysical Analysis}

Before biochemical and biophysical analysis, 3-month induced samples and dental and osteo-induced aggregates were washed three times in distilled water for 5 minutes and were dehydrated in heater for 2 days at $37^{\circ} \mathrm{C}$.

\section{X-Ray Diffraction}

X-ray diffraction (XRD) patterns were collected using a PanAnalytical X'Pert Pro equipped with X'Celerator detector powder diffractometer (PANalytical, Almelo, the Netherlands) using $\mathrm{Cu} \mathrm{K} \alpha$ radiation $(\lambda=1.5418 \AA$ ) generated at $40 \mathrm{kV}$ and $40 \mathrm{~mA}$. The instrument was configured with a $1 / 4^{\circ}$ divergence and $1 / 4^{\circ}$ antiscattering slits.
A standard quartz sample holder $1 \mathrm{~mm}$ deep, $20 \mathrm{~mm}$ high, and $15 \mathrm{~mm}$ wide was used. The diffraction patterns were collected within the $2 \theta$ range from $10^{\circ}$ to $85^{\circ}$ with a step size $(\Delta 2 \theta)$ of $0.02^{\circ}$ and a counting time of 60 seconds.

\section{Transmission Electron Microscopy}

Transmission electron microscopy (TEM) observations were performed using a Philips CM 100 instrument ( $80 \mathrm{kV})$. The powdered samples were dispersed in water, and then a few droplets of the slurry were deposited on holey-carbon foils supported on conventional copper microgrids. The images were recorded using a CCD digital camera.

\section{Statistical Analysis}

Statistical analysis was performed by Student's $t$-test. Data from experiments are expressed as mean $\pm \mathrm{SD}$ of three independent experiments.

\section{Results}

ASCs were isolated from human adipose tissue lipoaspirates without selection by immuno or chemical depletion. Cells were then seeded in a 100-mm culture plate, without an extracellular matrix substrate. Cells proliferated in proliferation medium containing 1.25\% type 0 human serum. The isolated ASC population expressed high levels for each of the following mesenchymal stem cell markers ${ }^{18,21-23}$ : CD10 $(74 \% \pm 2.5 \%), \operatorname{CD} 13(99 \% \pm 1 \%)$, CD29 (98\% $\pm 2 \%)$, CD44 (97\% $\pm 2.5 \%)$, CD49a (20\% \pm $3 \%), \operatorname{CD} 49 \mathrm{~d}(99 \% \pm 1 \%), \mathrm{CD} 59(99 \% \pm 1 \%), \mathrm{CD} 73$ $(99 \% \pm 1 \%), \operatorname{CD} 90(99 \% \pm 1 \%)$, and CD105 $(99 \% \pm$ $1 \%$ ), while exhibiting low expression levels for the following: CD34 (1\% $\pm 0.7 \%), \mathrm{CD} 45(0.3 \% \pm 0.1 \%), \mathrm{CD} 66 \mathrm{e}$ $(1.8 \% \pm 0.6 \%), \operatorname{CD} 117(0.5 \% \pm 0.5 \%), \mathrm{CD} 133(0.25 \% \pm$ $0.2 \%), \operatorname{KDR}(0.6 \% \pm 0.3 \%)$, and vascular endothelial cadherin $(0.2 \% \pm 0.1 \%)$ (Figure $2 \mathrm{~A})$; moreover, proliferating ASCs highly expressed Oct-4 isoform A, Nanog mRNAs, and proteins, showing that no significant differences among different individuals may be because age difference was small, supporting the hypothesis that these cells may have stemness properties (Figures 2, B-F). ${ }^{16,21-23}$

During the first 2 weeks of differentiation, spherical ASC aggregates underwent compaction, due to cell-cell interaction and extracellular matrix production, then peripheral tips started to enlarge as seen in the video (see Supplemental Video S1 at http://ajp.amjpathol.org). After 1 month, dental-induced ASC aggregates were sectioned and stained by hematoxylin-eosin. Hematoxylineosin clearly evidenced a three-layered aggregate morphology composed of i) an outer layer, which consisted of flattened cells with scanty cytoplasm, all around the aggregate; ii) an intermediate layer also all around the aggregate: this layer was not uniform consisting of elongated cells, which regionally increased its thickening by the effect of cell polarization, and polarized elongated cells became perpendicular to the other layers and appeared dispersed in an abundant extracellular matrix; 

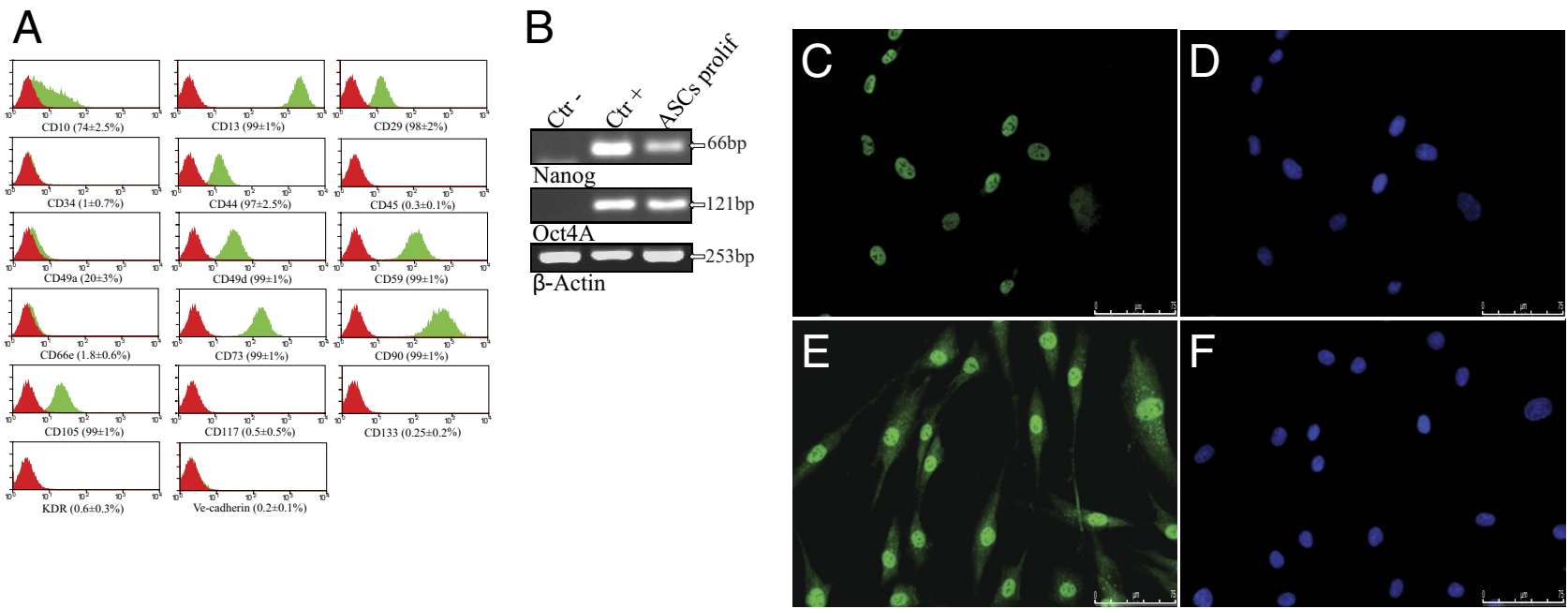

Figure 2. ASC characterization. A: ASC FACS analysis. Plots show isotype control IgG staining profile (red) versus specific antibody staining profile (green). The $\mathrm{x}$-axis shows relative fluorescence; the $\mathrm{y}$-axis, the number of events. Values represent averages and standard deviations of three independent samples. B, Nanog and Oct4 A RT-PCR. C-F: FITC-labeled immunofluorescences show Nanog and Oct4 A expression in proliferating ASCs. Nuclei were counterstained with DAPI Scale bar $=75 \mu \mathrm{m}$.

and finally iii) an inner layer composed of small cells with scanty cytoplasm with no preferential orientation (Figures $3, A$ and $B$ ). The model of invagination followed by a three-dimensional specific organization is supported by the observation that shorter time dental-induced ASC aggregates (2 weeks) showed only a bilayered three-dimensional structure, missing the intermediate polarized layer (see Supplemental Figure S1A at $h t t p: / /$ ajp.amjpathol.org).

The analysis of transcripts and proteins expressed by the developing aggregates was used to investigate cell differentiation progression. We evaluated the expression of ameloblastic proteins such as ameloblastin, expressed at high levels by ameloblasts and at low levels by odontoblasts and preodontoblasts ${ }^{24-26}$; enamelin, which represents only $1 \%$ of enamel matrix proteins ${ }^{27}$; amelogenin, the most abundant enamel protein representing $90 \%$ of total organic enamel matrix ${ }^{27,28}$; and MMP-20, involved in amelogenin and enamelin processing. ${ }^{29,30}$ Morotomi et $\mathrm{al}^{26}$ suggested that ameloblastin is more specific than other markers (ie, amelogenin and enamelin) for identifying the differentiated ameloblastic phenotype. Sequencing of RT-PCR amplification product evidenced ameloblastin mRNA de novo expression after differentiation induction (Figure 3C), and moreover 65-kDa native ameloblastin and proteolytic fragments were detected by immunoblotting (Figure 3D). Our results showed that ameloblastin was highly expressed in both the outer and intermediate layers, and there was a high degree of supranuclear positivity ${ }^{31}$ (Figure 3, E and F). IHC for ameloblastin performed on sections derived from dental-induced ASCs evidenced a higher cytoplasmic signal between the intermediate and inner layers but also that these proteins were expressed in a filamentous arrangement in the inner-layer extracellular matrix (Figure 3G).

After 2 weeks, ameloblastin was expressed mainly by the outer layer (see Supplemental Figure S1, B and C, at http://ajp.amjpathol.org). RT-PCR on differentiated ASCs showed enamelin expression only after dental induction
(Figure 3C); enamelin amplicon was confirmed by DNA sequence analysis. A $186-\mathrm{kDa}$ enamelin band, ${ }^{32}$ corresponding to posttranslational modified protein, was seen by immunoblotting only in induced ASC and positive control cells (Figure 3D). The weak band intensity was attributable to low protein expression because enamelin represents only $1 \%$ of enamel matrix proteins. ${ }^{27}$ $\mathrm{IHC}$ for enamelin performed on sections derived from dentally induced ASCs showed a higher cytoplasmic signal between the intermediate and inner layer concentrated in ameloblasts and odontoblasts. At the same time, as previously shown for ameloblastin, enamelin was expressed in the inner-layer extracellular matrix and arranged in filaments ${ }^{32}$ (Figure 3, $\mathrm{H}-\mathrm{J}$ ). ASCs induced for a shorter time (2 weeks) showed a faint diffuse signal for enamelin over the whole section, without specific localization (see Supplemental Figure S1, D and E, at http:// ajp.amjpathol.org). RT-PCR on ASCs showed amelogenin isoform 1, missing the exon 4 (343 bp), ${ }^{33}$ expression in both proliferating and differentiating cells; type 2 isoform, missing exons 3 to 4 (295 bp), ${ }^{33}$ was instead expressed only after dental induction (Figure 3C); cDNA identities were positively confirmed by sequencing. The longest isoform type 3 (385 bp) ${ }^{33}$ was not expressed by our cells (Figure 3C).

Amelogenin is secreted as a 189aa protein isoform 3 (20.7 kDa) but also as isoform 1, present in approximately $80 \%$ of total amelogenin, secreted as a native protein of $175 \mathrm{aa}(19.250 \mathrm{kDa})$, and isoform 2, approximately $19 \%$, composed of 159aa (17.490 kDa). 27,33,34 Immunoblot for differentiated ASCs showed amelogenin expression in both proliferating and differentiating cells, but, although during proliferation the band was single (isoform 1), after induction there were two less intense bands, one with the same mol. wt. as seen in proliferating cells and the other with lower mol. wt. (isoform 2) (Figure 3D). IHC for amelogenin on differentiated ASCs showed a diffuse cytoplasmic signal, in particular supranuclear. Moreover, high extracellular positivity was present between the in- 

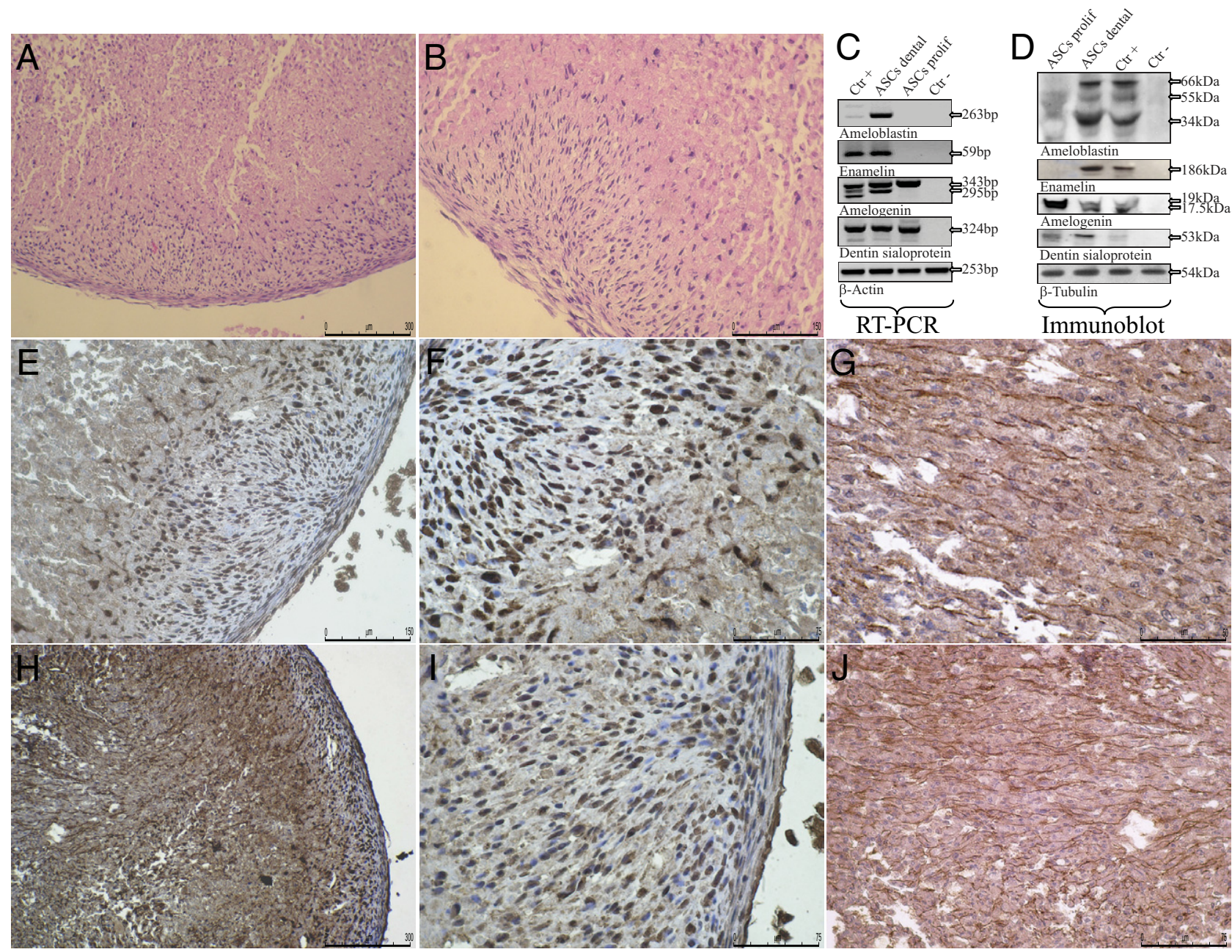

Figure 3. Similar dental bud morphology and expression and localization of ameloblastic markers. A and B: Hematoxylin-eosin staining demonstrates similar dental bud three-layered organization obtained after ASC aggregates were cultured for 1 month in dental-inducing medium. C and D: Ameloblastin, enamelin, amelogenin, MMP-20, and DSP PCR and immunoblot expression comparison in proliferating, induced, and control cells. A strong immunoreaction to anti-ameloblastin (E and $\mathbf{F})$ and anti-enamelin (H and $\mathbf{I})$ is observed in the cytoplasm of tall columnar cells in the intermediate layer of 1-month dental-induced aggregates. Both markers have an extracellular distribution in the inner layer. Higher magnification $(\mathbf{G}$ and $\mathbf{J})$ shows ameloblastin and enamelin extracellular filamentous distribution. Nuclei were counterstained with hematoxylin. Scale bars: $300(\mathbf{A}$ and $\mathbf{H}), 150(\mathbf{B}$ and $\mathbf{E}), 50(\mathbf{G})$, and $75 \mu \mathrm{m}(\mathbf{F}, \mathbf{I}$, and $\mathbf{J})$.

termediate and inner layers (Figures $4, \mathrm{~A}$ and B). Twoweek induced ASCs did not show any amelogenin signal (see Supplemental Figure S1, F and G, at http://ajp. amjpathol.org).

IHC showed MMP-20 expression in ASC cells. Positivity was mainly cytosolic and supranuclear in the outer layer ${ }^{30}$; on the contrary faint extracellular localization was detected in the inner layer (Figures 4, C and D). After two weeks, MMP-20 was expressed mainly in the outer layer (see Supplemental Figure S1, H and I, at http://ajp. amjpathol.org). DSP is mainly expressed in dentin, accounting for $5 \%$ to $8 \%$ of the noncollagenous protein content. ${ }^{35}$ DSP expression in differentiated ASCs correlates with ameloblastic (amelogenin, ameloblastin, and enamelin) marker localization between outer and inner layers but more specifically is mainly expressed in the lower intermediate layer (Figure 4, E and F). On the contrary, DSP was expressed over the whole section after 2 weeks (see Supplemental Figure S1, J and K, at http:// ajp.amjpathol.org). DSP mRNA was expressed in both proliferation and differentiation in ASCs as shown by RTPCR (Figure 3C), but we found that the protein was expressed only after dental induction as demonstrated by immunoblotting (Figure 3D).

The intermediate filament $\mathrm{Ck}-13$ is a protein expressed in tooth tissue but not in bone tissue; in fact, it is usually expressed in the stratified epithelia that line the oral cavity. ${ }^{36} \mathrm{IHC}$ for $\mathrm{Ck}-13$ expression analysis revealed diffuse signal over the whole section with an extracellular distribution in the outer similar epithelial layer, mainly intracellular in the polarized intermediate layer and supranuclear in the inner layer (Figure 5, A and B). After 2 weeks, Ck-13 was expressed mainly in the inner layer with supranuclear localization (see Supplemental Figure S2A at $h t t p: / /$ ajp.amjpathol.org).

Ck14 is expressed only in the dental epithelium and not in the mesenchyme of the tooth germ or in any of the surrounding tissues in the mandible. ${ }^{37}$ After ASC induction, Ck-14 expression was negative in the inner layer and positive in the outer and intermediate layers, where signal 

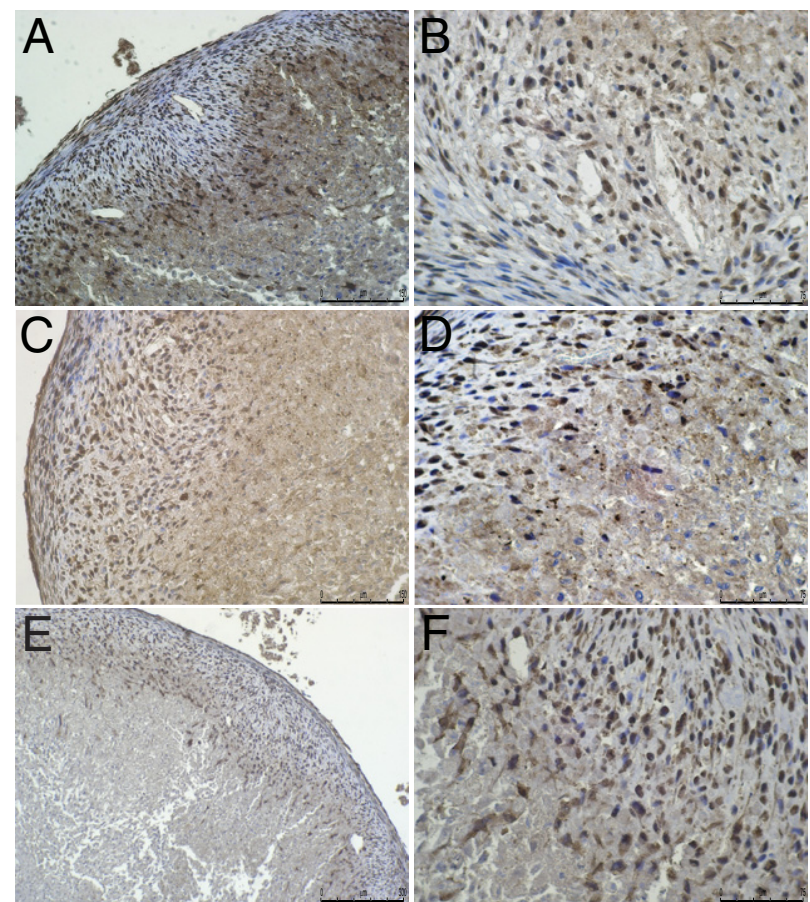

Figure 4. Other amelo-odontoblastic marker expression and localization. A strong immunoreaction to amelogenin ( $\mathbf{A}$ and $\mathbf{B})$, MMP-20 ( $\mathbf{C}$ and $\mathbf{D})$, and DSP ( $\mathbf{E}$ and $\mathbf{F})$ is observed in tall columnar cells in the intermediate layer of 1-month dental-induced aggregates. Nuclei were counterstained with hematoxylin. Scale bars: 300 (A and $\mathbf{C}), 150(\mathbf{E})$, and $75 \mu \mathrm{m}(\mathbf{B}, \mathbf{D}$, and $\mathbf{F})$.

was cytoplasmic and supranuclear (Figure 5, C and D). Two-week induced ASCs expressed Ck-14 only in the outer layer (see Supplemental Figure S2B at http://ajp. amjpathol.org).

We also used IHC to evaluate Ck-19 expression, which represents another epithelial marker involved in tooth morphogenesis. ${ }^{38}$ In our experiments, Ck19 was faintly expressed and mainly concentrated in the outer and intermediate layers (Figure 5, E and F). Moreover, it was not expressed in two-week induced ASC aggregates (see Supplemental Figure S2C at http://ajp.amjpathol.org). In induced ASCs, E-cad was specifically expressed by the intermediate to the internal layer (Figure 5, G and $H$ ), whereas $\mathrm{N}$-cad was mainly expressed in the intermediate layer (Figure 5, I and J), showing specific coexpression with the E-cad zone. Shorter time induced ASC aggregates expressed E-cad over the whole section but mainly in the outer layer, whereas $\mathrm{N}$-cad was not expressed (see Supplemental Figure S2, D and E, at http://ajp.amjpathol. org).

In our experiments, collagen type 4 was specifically expressed in the lower intermediate layer and in the upper layer (Figures 6, A and B), and MMP-2 faint expression was mainly localized in the outer and intermediate layers, as shown by IHC (Figure 6, C and D).

Two-week induced aggregates showed collagen type 4 expression in a tight zone between inner and outer layers (see Supplemental Figure S2F at http://ajp.amjpathol.org), and MMP-2 was not expressed (see Supplemental Figure S2G at $h$ ttp://ajp.amjpathol.org).

We also analyzed the expression of mesenchymal markers involved in tooth morphogenesis such as $\beta_{1}$ integrin (CD29), which is expressed in basement membrane areas and in mesenchymal cells throughout bud to cap stages of dental development ${ }^{39}$ and collagen type 3 . Both have been used to identify the dental mesenchymal derivative dental papilla. ${ }^{40} \beta_{1}$-integrin was greatly expressed from the inner layer to the polarized intermediate layer, as shown in induced ASC aggregates by IHC (Figure $6, \mathrm{E}$ and $\mathrm{F}$ ).

$\mathrm{IHC}$ also demonstrated that collagen 3 expression was mainly extracellular in the inner layer, but both intracellu-

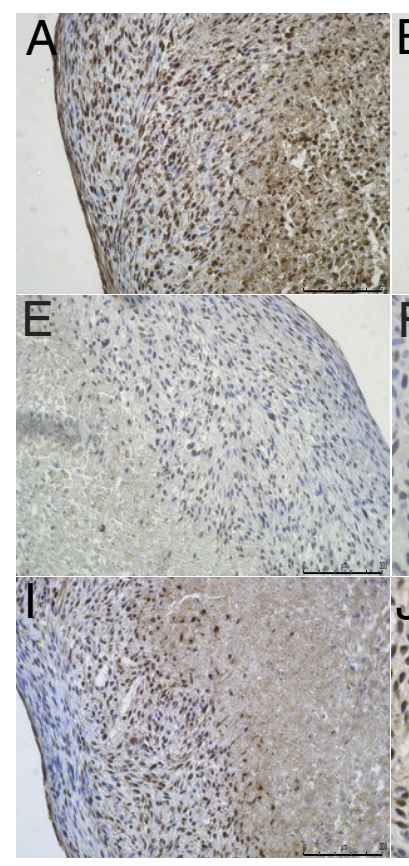

\section{B}
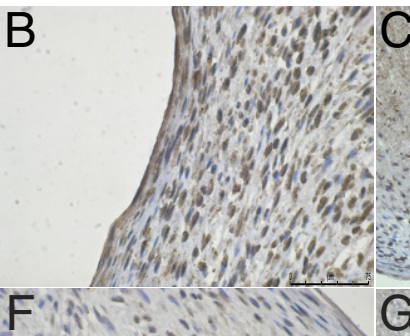

G
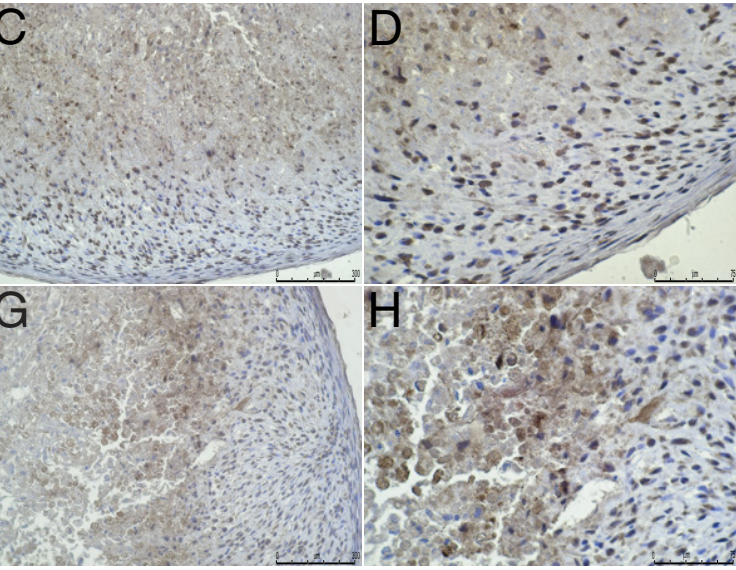

Figure 5. Epithelial marker localization. IHC showing that Ck-13 (A and $\mathbf{B}$ ) a Ck expressed in dental tissues but not in bone tissues, is highly expressed over the whole ASC 1-month dental-induced aggregate; instead, Ck-14 (C and $\mathbf{D})$ and Ck-19 (E and F) stain is faint and localized in the outer and intermediate layers. E-cad is highly expressed and is distributed between the inner and intermediate layers ( $\mathbf{G}$ and $\mathbf{H}$ ). N-cad is mainly expressed in the intermediate layer and partially overlaps with E-cad in 1-month dental-induced aggregates (I and $\mathbf{J}$ ). Nuclei were counterstained with hematoxylin. Scale bars: $300(\mathbf{A}, \mathbf{C}, \mathbf{E}, \mathbf{G}$, and $\mathbf{I})$ and $75 \mu \mathrm{m}(\mathbf{B}, \mathbf{D}, \mathbf{F}, \mathbf{H}$, and $\mathbf{J})$. 

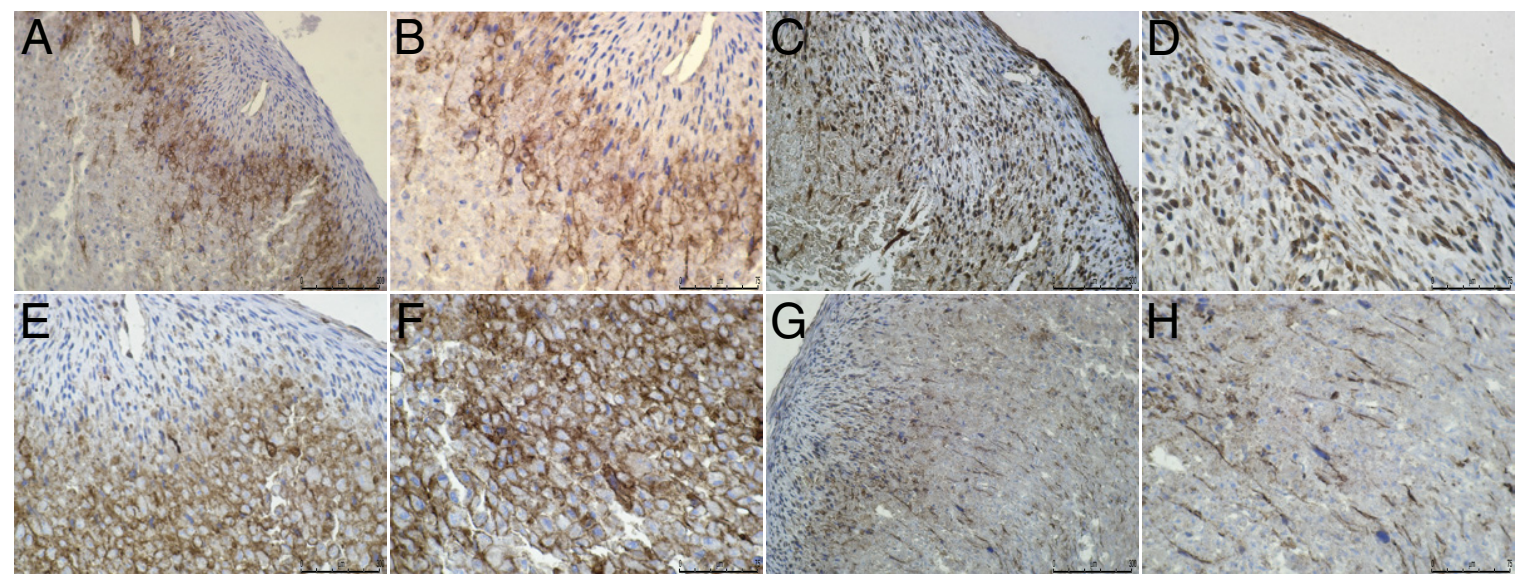

Figure 6. Basement membrane and mesenchymal marker localization. Collagen type 4 immunohistochemical staining localizes in the basement membrane between the intermediate and inner layers (A and $\mathbf{B})$. MMP-2 (C and $\mathbf{D})$, a protein involved in basement membrane degradation and epithelium invagination, is mainly expressed in the outer and inner layers. Expression of the mesenchymal markers $\beta_{1}$-integrin and collagen type 3 was found in the inner layer of 1 -month dental-induced aggregates $(\mathbf{E}-\mathbf{H})$. Nuclei were counterstained with hematoxylin. Scale bars: $300(\mathbf{A}, \mathbf{C}, \mathbf{E}$, and $\mathbf{G})$ and $75 \mu \mathrm{m}(\mathbf{B}, \mathbf{D}, \mathbf{F}$, and $\mathbf{H})$.

lar and extracellular low expression was present in the intermediate layer.

Interestingly, in the inner layer collagen 3 formed fibers arranged in a parallel bundles (Figure 6, $G$ and $H$ ) as previously reported for ameloblastin and enamelin. Twoweek aggregates confirm $\beta_{1}$-integrin and collagen 3 expression in the inner layer (see Supplemental Figure S2, $\mathrm{H}$ and I, at http://ajp.amjpathol.org).

To test HA formation, 3-month dental-induced ASC aggregates were ground before the analysis and were subjected to XRD. In Figure 7A, we reported the XRD pattern of 3-month ASC dental-induced aggregates (blue), 3-month human DPSCs (violet), and bone marrow-derived stem cell (green) osteo-induced aggregates. The XRD pattern shows the typical diffraction peaks of $\mathrm{HA}$ around $25.8^{\circ}$ and $32^{\circ}$ of $2 \theta$ and sodium chloride at $27.3^{\circ}$ and $31.6^{\circ}$ of $2 \theta$ (Figure 7A). ${ }^{41,42}$ No additional reflections due to other phases or $\mathrm{HA}$ precursors, such as octacalcium phosphate, were observed. Natural bioapatite texture is responsible for the increased intensity of the $25.8^{\circ}$ lines for planar oriented specimens with the analyzed surface perpendicular to the longer bone axis. Thus, an analysis of the (002) lines is feasible because the $\mathrm{c}$-axis of bioapatite crystals has a strongly preferred orientation in the direction parallel to the bone axis. ${ }^{43,44}$ Dental-induced ASC diffraction patterns generally showed more evident reflections then osteo-induced samples, and the intensity of the reflection at $25.8^{\circ}$ clearly increased its intensity moving from the DPSC to the ASC samples after induction.

Aggregates were analyzed by TEM. Images have been reported in Figure $7, \mathrm{~B}$ and $\mathrm{C}$. The mineral phase in induced ASC aggregates shows that aggregates comprise elongated platelike crystals with two distinct patterns. In Figure 7B, crystals are approximately $50 \mathrm{~nm}$ long and strongly associated but do not show any clear edges, and the shape of the crystal units forming the aggregate is not clear. In Figure 7C, crystals are longer (approximately $200 \mathrm{~nm}$ ), are strongly associated, and also have well-defined edges and preferential orientation.

\section{Discussion}

In this study, we used selective culture conditions to isolate an ASC population as confirmed by the molecular characterization. ASCs were then used to test their stemness in vitro. To this purpose, in the present study we examined whether an aggregated mesenchyme-derived ASC, maintained in dental-inducing medium in the absence of synthetic scaffolds, was able to differentiate into a similar three-dimensional dental bud structure.

One-month induced ASC aggregates showed that fine three-dimensional organization, cell morphology, and spatial orientation were different starting from the outer to the inner layer, evidencing stronger cell positional specification when compared with two-week induced ASCs. Outer layer spatial orientation resembled that of a multilayered epithelial tissue, according to stratified oral epithelial tissue.

Assays results confirmed the presence and localization of specific Cks (13, 14, and 19), mainly between the outer and intermediate layers, supporting the presence of a layer expressing mainly epithelial markers. During enamel organ morphogenesis, the expressed Cks do not show differences related to a specific stage of differentiation, except for Ck-14, which is substituted by Ck-19 in the enamel epithelium. ${ }^{38}$ Coexpression of $\mathrm{Ck}-14$ and Ck-19 in induced ASCs may suggest that they could be in an intermediate phase between the bud to cap stage.

In our experiments, after 1-month induction an intermediate cell layer mass invaginated into the underlying inner layer and became polarized as a specific result of cellular rearrangements. The intermediate layer was composed of thickened regions containing lengthened polarized cells in active secretion. Such three-dimensional morphology reminds the enamel knots, the structural regions directing cusp formation during dental morphogenesis. ${ }^{2}$ An important characteristic of dental cells is the polarity of odontoblasts, ameloblasts, and cementoblasts. These cells secrete their extracellular matrix proteins starting from a common basement membrane, indentified as the dentin enamel junction and the dentin cement junc- 

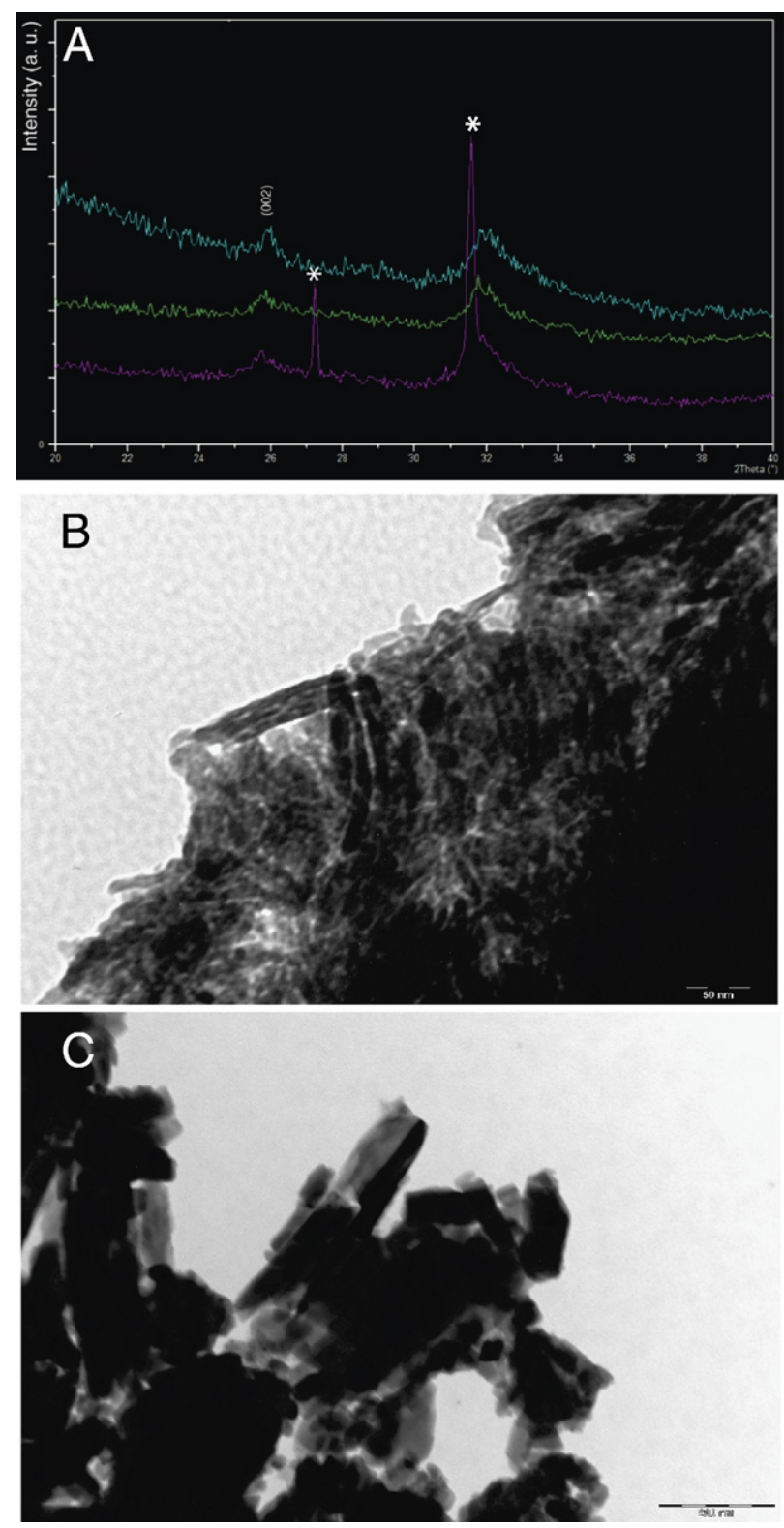

Figure 7. Physical-chemical HA nanocrystal evidence. A: XRD pattern of 3-month ASC dental-induced aggregates (blue), 3-month human DPSC aggregates (violet), and human bone marrow-derived stem cell (green) osteo-induced aggregates. XRD shows HA typical diffraction peaks. Relative intensity suggests a preferential orientation of crystalline units in ASC dental-induced aggregates compared with osteo-induced random aggregates. The $(002)$ diffraction peak of HA is diagnostic of orientation. Asterisks mark diffraction peaks due to the presence of sodium chloride. TEM analysis shows two distinct pattern of HA crystals: $50 \mathrm{~nm}(\mathbf{B})$ and $200 \mathrm{~nm}(\mathbf{C})$, as in bone-dentin and enamel, respectively. Scale bars: 50 and $200 \mathrm{~nm}$.

tion. Such cellular rearrangement is achieved by basement membrane contraction and is mediated by binding to cell surface receptors. ${ }^{45}$ Invasion has been suggested to involve the interaction among the basement membrane, proteolysis, and integrins. ${ }^{46,47}$ MMP proteolytic remodeling ${ }^{48,49}$ not only removes the basement membrane but also provides a promigratory microenvironment. ${ }^{47,50}$

Type 4 collagen is present in the dental basement membrane during the bud to cap stage of tooth development but disappears at later stages because of the MMP action ${ }^{51,52 \text {; }}$ one of these proteinases is gelatinase A (MMP-2), whose expression has been correlated with collagen 4 and extracellular matrix degradation during the early stages of tooth development and specifically when epithelial cells migrate into the underlying mesenchyme, inducing and maintaining cell polarity and differentiation. ${ }^{49,53,54}$ In our experiments, type 4 collagen was expressed only in the inner half of the intermediate layer and seemed to demarcate the future dentin enamel junction. At the same time, MMP-2, which is involved in type 4 collagen degradation, is coexpressed with type 4 collagen, correlating with the presence of a basement membrane under rearrangement, which modulates dental morphogenesis. ${ }^{54}$

Ameloblastic and odontoblastic markers are highly expressed in the intermediate inner layers.

During tooth development, E-cad is initially expressed in the dental epithelial cells until it reaches cap stage and then disappears, which contrasts with the missing expression in mesenchymally derived odontoblasts; on the contrary, $\mathrm{N}$-cad is expressed only in epithelium-derived ameloblasts. ${ }^{55,56}$

Moreover, the concomitant $\mathrm{N}$-cad expression, which according to Heymann et $\mathrm{al}^{56}$ is important for enameldentin matrix secretion, confirms the presence of an active secretion layer in our sample.

Also, specific colocalization of E-cad and N-cad represents evidence of cell polarization and differentiation, as confirmed by Heymann et al, ${ }^{56}$ during in vivo tooth development for both the ameloblastic and odontoblastic phenotypes.

We did not find significant differences between ameloodontoblastic marker localization. These specific markers are expressed by the elongated polarized cells and reach higher levels in the regions marked by the type 4 collagen, $\mathrm{E}$-cad, and $\mathrm{N}$-cad expression. Although there is no specific marker that identifies ameloblasts, recent results by $\mathrm{IHC}$ on developing tooth sections by Morotomi et $\mathrm{al}^{26}$ suggest that ameloblastin may be a useful marker to detect the ameloblastic phenotype. Cells in the intermediate layer expressed ameloblastin, supporting the possibility of ASC ameloblastic differentiation as also confirmed by type 2 isoform amelogenin cell-specific expression after differentiation as shown by lacob et al. $^{33}$

$\mathrm{IHC}$ showed higher cytoplasmic signals of ameloblastin and enamelin between the intermediate and inner layers. These proteins showed a filamentous arrangement in the inner-layer extracellular matrix, suggesting the presence of the cleavage products at the rod and interrod regions of the enamel and dentin matrix, as shown by Hu et al. ${ }^{32}$

It has been reported that amelogenin binds to Ck-14 and $\mathrm{Ck}-5$ in supranuclear cytoplasm to be properly folded $^{57-59}$ and that MMP-20 is necessary for amelogenin and enamelin processing. ${ }^{29,30}$ These evidences could explain the supranuclear MMP-20, Ck-14, amelogenin, and enamelin coexpression in induced ASC aggregate intermediate layer.

The inner layer is supposed to possess a mesenchyme-derived phenotype, which is not organized and consists of small, nonoriented cells. This hypothesis is suggested by Salmivirta et al, ${ }^{39}$ who evidenced $\beta_{1}$-integrin expression during dental development mainly in mesenchyme-derived cells. 
After ASC induction, $\beta_{1}$-integrin (CD29) is uniformly and specifically expressed in the inner layer of the aggregates.

Abrahão et $\mathrm{a}^{40}$ demonstrated that type 3 collagen is a regular component of the papillae connective tissue, appearing as fibers arranged in parallel. Our experiments showed a similar type 3 collagen expression pattern only in the inner layer.

Bones and teeth are characterized by different HA crystal structure, composition, morphology, size, and orientation. In bone and dentin, HA crystals represent 50\% to $70 \%$ of the mass, are nanometer size, and are scattered in the organic matrix with an average length of 50 $\mathrm{nm}$. Dental enamel has a much larger inorganic content, up to $90 \%$, and is formed by strongly polarized prismatic crystals of larger dimensions, about $200 \mathrm{~nm}$ in length. ${ }^{41,42,60,61}$ Induced ASC aggregates produce spatially oriented HA nanocrystals with variable length, approximately $200 \mathrm{~nm}$, as in enamel, but also approximately $50 \mathrm{~nm}$ as in bone and dentin, as shown by XRD and TEM. Dental induction not only increased the HA crystallinity but also varied length and morphologic features and favored specific spatial orientation.

We isolated a single population of ASCs, which may be aggregated and induced to transdifferentiate in vitro, obtaining a specific three-dimensional organization and phenotype resembling a dental bud. This result was obtained without using any kind of structural matrix or scaffold to guide the process. The major achievement of our experimental approach is that our ASC aggregates reproduced in vitro the epithelial-mesenchymal interactions occurring in vivo and showed a three-dimensional structure comprising an intermediate structure similar to a basement membrane. Epithelial-mesenchymal interactions are the hallmark of tooth development and are involved in many other organ morphogenetic processes. These complicated, sequential, reciprocal interactions are mediated by the spatiotemporal expression of tooth-related genes (approximately 300 ) and by the secretion of growth and transcription factors (approximately 100) that are reiteratively used in regulatory loops (Figure 1). ${ }^{62}$ An important protein involved in dental morphogenesis regulation is BMP-4. It has been suggested that BMP-4 acts antagonistically to FGF-8 to produce localized sites of neural crest-derived mesenchyme that express $P A X-9$ and specify where teeth will develop. ${ }^{63,64}$ It was also reported that during early dental bud stage organogenesis, epithelial BMP-4 (via MSX-1) induces the production of mesenchymal BMP-4, whereas epithelial FGF-8 induces mesenchymal activin $\beta A$. The epithelial cells, under the influence of BMP- 4 and activin $\beta$ A, start proliferating and intrude within the mesenchyme in a cylinderlike structure with a bulblike bud at the end; then in late bud stage, PAX-9 expression is necessary for mesenchymal condensation as a consequence of ectomesenchymal cells proliferation and accumulation around each epithelial bud. ${ }^{3}$ Our studies try to recreate an in vitro simplified model of dental development and at the same time provide a convenient tool that may be used to better understand reciprocal exchange of signals between epithelial and mesenchymal germ layers. Furthermore, the present study could overcome the previous limitations and shortcomings in the field by providing a single cell type isolated from human adult adipose tissue, which may differentiate into dental bud-like aggregates and possibly could be terminally induced in vivo into the host alveolus to provide a dental regenerative therapy.

\section{Acknowledgments}

We thank Andrea Gallina and Sonia Perucci for their technical support.

\section{References}

1. Sharpe PT, Young CS: Test-tube teeth. Sci Am 2005, 293:34-41

2. Zhang YD, Chen Z, Song YQ, Liu C, Chen YP: Making a tooth: growth factors, transcription factors, and stem cells. Cell Res 2005, 15:301-316

3. Koussoulakou DS, Margaritis LH, Koussoulakos SL: A curriculum vitae of teeth: evolution, generation, regeneration. Int J Biol Sci 2009, 5:226-243

4. Sartaj R, Sharpe PT: Biological tooth replacement. J Anat 2006, 209:503-509

5. Iwatsuki S, Honda MJ, Harada H, Ueda M: Cell proliferation in teeth reconstructed from dispersed cells of embryonic tooth germs in a three-dimensional scaffold. Eur J Oral Sci 2006, 114:310-317

6. Kikuchi H, Suzuki K, Sakai N, Yamada S: Odontoblasts induced from mesenchymal cells of murine dental papillae in three-dimensional cell culture. Cell Tissue Res 2004, 317:173-185

7. Nakao K, Morita R, Saji Y, Ishida K, Tomita Y, Ogawa M, Saitoh M Tomooka $Y$, Tsuji T: The development of a bioengineered organ germ method. Nat Methods 2007, 4:227-230

8. Hu B, Nadiri A, Bopp-Kuchler S, Perrin-Schmitt F, Wang S, Lesot H Dental epithelial histomorphogenesis in the mouse: positional information versus cell history. Arch Oral Biol 2005, 50:131-136

9. Mina M, Kollar EJ: The induction of odontogenesis in non-odontogenic mesenchyme combined with early murine mandibular arch epithelium. Arch Oral Biol 1987, 32:123-127

10. Ikeda E, Tsuji T: Growing bioengineered teeth from single cells: potential for dental regenerative medicine. Expert Opin Biol Ther 2008, 8:735-744

11. Gronthos S, Simmons PJ: The growth factor requirements of stro-lpositive human bone marrow stromal precursors under serum-deprived conditions in vitro. Blood 1995, 85:929-940

12. Ferro $F$, Falini $G$, Spelat $R$, D'Aurizio $F$, Puppato $E$, Pandolfi $M$, Beltrami AP, Cesselli D, Beltrami CA, Ambesi-Impiombato FS, Curcio $\mathrm{F}$ : Biochemical and biophysical analyses of tissue-engineered bone obtained from three-dimensional culture of a subset of bone marrow mesenchymal stem cells. Tissue Eng Part A 2010, 16:3657-3667

13. Bieback K, Hecker A, Kocaomer A, Lannert H, Schallmoser K, Strunk $D$, Kluter $\mathrm{H}$ : Human alternatives to fetal bovine serum for the expansion of mesenchymal stromal cells from bone marrow. Stem Cells 2009, 27:2331-2341

14. Tondreau T, Lagneaux L, Dejeneffe M, Delforge A, Massy M, Mortier $\mathrm{C}$, Bron D: Isolation of BM mesenchymal stem cells by plastic adhesion or negative selection: phenotype, proliferation kinetics and differentiation potential. Cytotherapy 2004, 6:372-379

15. Curcio F, Ambesi-Impiombato FS, Perrella G, Coon HG: Long-term culture and functional characterization of follicular cells from adult normal human thyroids. Proc Natl Acad Sci U S A 1994, 91:9004-9008

16. Liedtke S, Stephan M, Kogler G: Oct4 expression revisited: potential pitfalls for data misinterpretation in stem cells. Biol Chem 2008, 389:845-850

17. Gallagher MF, Flavin RJ, Elbaruni SA, Mc Inerney JK, Smyth PC, Salley YM, Vencken SF, O'Toole SA, Laois A, Lee MY, Denning K, Li J, Aherne ST, Lao KQ, Martin CM, Sheils OM, O'Leary JJ: Regulation of microRNA biosynthesis and expression in $2102 \mathrm{Ep}$ embryonal carcinoma stem cells is mirrored in ovarian serous adenocarcinoma patients. J Ovarian Res 2009, 16:2-19

18. Beltrami AP, Cesselli D, Bergamin N, Marcon P, Rigo S, Puppato E D'Aurizio F, Verardo R, Piazza S, Pignatelli A, Poz A, Baccarani U, Damiani D, Fanin R, Mariuzzi L, FinatoN, Masolini P, Burelli S, Belluzzi O, Schneider C, Beltrami CA: Multipotent cells can be generated in 
vitro from several adult human organs (heart, liver and bone marrow). Blood 2007, 110:3438-3446

19. D'Ippolito G, Diabira S, Howard GA, Menei P, Roos BA, Schiller PC: Marrow-isolated adult multilineage inducible (MIAMI) cells, a unique population of postnatal young and old human cells with extensive expansion and differentiation potential. J Cell Sci 2004, 117:2971-2981

20. Chomczynski P, Sacchi N: Single-step method of RNA isolation by acid guanidinium thiocyanate-phenol-chloroform extraction. Anal Biochem 1987, 162:156-159

21. Zuk PA, Zhu M, Ashjian P, De Ugarte DA, Huang JI, Mizuno H, Alfonso ZC, Fraser JK, Benhaim P, Hedrick MH: Human adipose tissue is a source of multipotent stem cells. Mol Biol Cell 2002, 13:4279-4295

22. Pittenger MF, Martin A: Mesenchymal stem cells and their potential as cardiac therapeutics. Circ Res 2004, 95:9-20

23. Zuk PA: The intracellular distribution of the ES cell totipotent markers oct4 and sox 2 in adult stem cells differs dramatically according to commercial antibody used. J Cell Biochem 2009, 106:867-877

24. Fong CD, Hammarström L, Lundmark C, Wurtz T, Slaby I: Expression patterns of RNAs for amelin and amelogenin in developing rat molars and incisors. Adv Dent Res 1996, 10:195-200

25. Lee SK, Krebsbach PH, Matsuki Y, Nanci A, Yamada KM, Yamada Y: Ameloblastin expression in rat incisors and human tooth germs. Int $J$ Dev Biol 1996, 40:1141-1150

26. Morotomi T, Kawano S, Toyono T, Kitamura C, Terashita M, Uchida T, Toyoshima K, Harada $\mathrm{H}$ : In vitro differentiation of dental epithelial progenitor cells through epithelial-mesenchymal interactions. Arch Oral Biol 2005, 50:695-705

27. Hu JC, Sun X, Zhang C, Simmer JP: A comparison of enamelin and amelogenin expression in developing mouse molars. Eur J Oral Sci 2001, 109:125-132

28. Nagano T, Oida S, Ando H, Gomi K, Arai T, Fukae M: Relative levels of mRNA encoding enamel proteins in enamel organ epithelia and odontoblasts. J Dent Res 2003, 82:982-986

29. Bartlett JD, Simmer JP: Proteinases in developing dental enamel. Crit Rev Oral Biol Med 1999, 10:425-441

30. Bourd-Boittin K, Septier D, Hall R, Goldberg M, Menashi S: Immunolocalization of enamelysin (matrix metalloproteinase-20) in the forming rat incisor. J Histochem Cytochem 2004, 52:437-445

31. MacDougall M, Simmons D, Gu TT, Forsman-Semb K, Mårdh CK, Mesbah M, Forest N, Krebsbach PH, Yamada Y, Berdal A: Cloning, characterization and immunolocalization of human ameloblastin. Eur J Oral Sci 2000, 108:303-310

32. Hu JCC, Yamakoshi Y: Enamelin and autosomal-dominant amelogenesis imperfecta. Crit Rev Oral Biol Med 2003, 14:387-398

33. lacob S, Veis A: Identification of temporal and spatial expression patterns of amelogenin isoforms during mouse molar development Eur J Oral Sci 2006, 114:194-200

34. Stephanopoulos G, Garefalaki ME, Lyroudia K: Genes and related proteins involved in amelogenesis imperfecta. J Dent Res 2005 $84: 1117-1126$

35. Godovikova V, Ritchie HH: Dynamic processing of recombinant dentin sialoprotein-phosphophoryn protein. J Biol Chem 2007, 282: 31341-31348

36. Trueb B, Taeschler S, Schild C, Lang NP: Expression of phosphoproteins and amelotin in teeth. Int J Molec Med 2007, 19:49-54

37. Tabata MJ, Matsumura T, Liu JG, Wakisaka S, Kurisu K: Expression of cytokeratin 14 in ameloblast-lineage cells of the developing tooth of rat, both in vivo and in vitro. Arch Oral Biol 1996, 41:1019-1027

38. Domingues MG, Jaeger MM, Araújo VC, Araújo NS: Expression of cytokeratins in human enamel organ. Eur J Oral Sci 2000, 108:43-47

39. Salmivirta K, Gullberg D, Hirsch E, Altruda F, Ekblom P: Integrin subunit expression associated with epithelial-mesenchymal interactions during murine tooth development. Dev Dyn 1996, 205:104-113

40. Abrahão IJ, Martins MD, Katayama E, Antoniazzi JH, Segmentilli A, Marques MM: Collagen analysis in human tooth germ papillae. Braz Dent J 2006, 17:208-212

41. Rey C: Calcium phosphate and bone mineral: difference in composition, structure and properties. Biomaterials 1990, 11:5-13

42. Currey JD: Bones: Structure and Mechanics. Princeton, NJ, Princeton University Press, 2002.
43. Danilchenko SN, Kukharenko OG, Moseke C, Protsenko YI, Sukhodub LF, Sulkio-Cleff B: Determination of the bone mineral crystallite size and lattice strain from diffraction line broadening. Cryst Res Technol 2002, 37:1234-1240

44. Sasaki N, Sudoh Y: X-ray pole figure analysis of apatite crystals and collagen molecules in bone. Calcif Tissue Int 1997, 60:361-367

45. Schiro JA, Chan BMC, Roswit WT, Kassner PD, Pentland AP, Hemier ME, Eisen AZ, Kupper TS: Integrin $\alpha 2 \beta 1$ (VAL-2) mediates reorganization and contraction of collagen matrices by human cells. Cell 1991, 67:403-410

46. Davis GE, Bayless KJ, Mavila A: Molecular basis of endothelial cell morphogenesis in three-dimensional extracellular matrices. Anat Rec 2002, 268:252-275

47. Galvez BG, Matias-Roman S, Yanez-Mo M, Sanchez-Madrid F, Arroyo AG: ECM regulates MT 1-MMP localization with $\beta 1$ or $\alpha \mathrm{V} \beta 3$ integrins at distinct cell compartments modulating its internalization and activity on human endothelial cells. J Cell Biol 2002, 159:509-521

48. Birkedal-Hansen $\mathrm{H}$ : Proteolytic remodelling of extracellular matrix. Curr Opin Cell Biol 1995, 7:728-735

49. Nagase H, Woessner JF Jr: Matrix metalloproteinases. J Biol Chem 1999, 274:21491-21494

50. Koshikawa N, Giannelli G, Cirulli V, Miyazaki K, Quaranta V: Role of cell surface metalloprotease MT 1-MMP in epithelial cell migration over laminin-5. J Cell Biol 2000, 148:615-624

51. Olson MW, Toth M, Gervasi DC, Sado Y, Ninomiya Y, Fridman R: High affinity binding of latent matrix metalloproteinase-9 to the alpha2(IV) chain of collagen IV. J Biol Chem 1998, 273:10672-10681

52. Lesot H, Osman M, Ruch JV: Immunofluorescent localization of collagens, fibronectin, and laminin during terminal differentiation of odontoblasts. Dev Biol 1981, 82:371-381

53. Sahlberg C, Reponen P, Tryggvason K, Thesleff I: Association between the expression of murine $72 \mathrm{kDa}$ type IV collagenase by odontoblasts and basement membrane degradation during mouse tooth development. Arch Oral Biol 1992, 37:1021-1030

54. Yoshiba N, Yoshiba K, Stoetzel C, Perrin-Schmitt F, Cam Y, Ruch YV, Lesot $\mathrm{H}$ : Temporospatial gene expression and protein localization of matrix metalloproteinases and their inhibitors during mouse molar tooth development. Dev Dyn 2003, 228:105-112

55. Fausser JL, Schlepp O, Aberdam D, Meneguzzi G, Ruch JV, Lesot H: Localization of antigens associated with adherens junctions, desmosomes, and hemidesmosomes during murine molar morphogenesis. Differentiation 1998, 63:1-11

56. Heymann R, About I, Lendahl U, Franquin JC, Obrink B, Mitsiadis TA: $\mathrm{E}$ - and $\mathrm{N}$-cadherin distribution in developing and functional human teeth under normal and pathological conditions. Am J Pathol 2002 , 160:2123-2133

57. Ravindranath RM, Tam WY, Nguyen P, Fincham AG: The enamel protein amelogenin binds to the $\mathrm{N}$-acetyl-D-glucosamine-mimicking peptide motif of cytokeratins. J Biol Chem 2000, 275:39654-39661

58. Ravindranath RM, Tam WY, Bringas P Jr, Santos V, Fincham AG: Amelogenin-cytokeratin 14 interaction in ameloblasts during enamel formation. J Biol Chem 2001, 276:36586-36597

59. Ravindranath RM, Basilrose RM Sr, Ravindranath $\mathrm{NH}$, Vaitheesvaran $\mathrm{B}$ : Amelogenin interacts with cytokeratin-5 in ameloblasts during enamel growth. J Biol Chem 2003, 278:20293-20302

60. Vallet-Regi M, Gonzalez-Calbet JM: Calcium phosphates as substitution of bone tissues Prog Solid State Chemistry 2004, 32:1-31

61. Boskey AL, Spevak L, Paschalis E, Doty SB, McKee MD: Osteopontin deficiency increases mineral content and mineral crystallinity in mouse bone. Calcif Tissue Int 2002, 71:145-154

62. Jernvall J, Thesleff I: Reiterative signaling and patterning during mammalian tooth morphogenesis. Mech Dev 2000, 92:19-29

63. Neubüser A, Peters H, Balling R, Martin GR: Antagonistic interactions between FGF and BMP signalling pathways: a mechanism for positioning the sites of tooth formation. Cell 1997, 90:247-255

64. Laurikkala J, Kassai Y, Pakkasjärvi L, Thesleff I, Itoh N: Identification of a secreted BMP antagonist, ectodin, integrating BMP. FGF, and $\mathrm{SHH}$ signals from the tooth enamel knot. Dev Biol 2003 264:91-105 